Jurnal Konstruksi Hukum | ISSN: 2746-5055

Vol. 2, No. 3, September 2021 Hal. 605-609 |Tersedia online di

https://www.ejournal.warmadewa.ac.id/index.php/jukonhum

DOI:http://doi.org/10.22225/jkh.2.3.3665.605-609

\title{
KEDUDUKAN PEREMPUAN MULIH DAHA DALAM KELUARGA DAN AKIBAT HUKUM TERHADAP ANAK DI DESA ADAT MENGWITANI
}

\author{
Putu Ayu Devi Kardila, I Nyoman Putu Budiartha, I Wayan Rideng \\ Fakultas Hukum Universitas Warmadewa Denpasar, Bali- Indonesia \\ Devikardila05@gmail.com, Budiarthaputu59@gmail.com, wyrideng@gmail.com
}

\begin{abstract}
Abstrak
Perempuan yang kembali ke rumah asalnya karena terjadinya suatu perceraian maka statusnya disebut dengan mulih daha (kembali gadis). Dengan tersebut perempuan mulih daha tetap melakukan swadharmanya (kewajibannya) kepada orang tuanya di rumah asalnya. Apabila perkawinan putus dikarenakan perceraian juga mempunyai akibat hukum terhadap anak. Berdasarkan latar belakang yang telah diuraikan, maka tujuan dari penelitian ini yaitu untuk mengetahui bagaimana status hukum perempuan Mulih Daha dan bagaimana akibat hukum terhadap anak yang dibawa perempuan Mulih Daha ke rumah asalnya. Metode penelitian dalam penulisan ini menggunakan metode penelitian empiris. Hasil penelitian ini menunjukan bahwa perempuan mulih daha tidak berhak menuntut kembali hak mewaris di rumah asalnya. Hak dan kewajiban orang tua yang sudah melakukan proses perceraian terhadap anaknya tetap harus dilaksanakan yang diatur dalam Pasal 26 ayat (1) dan (2) Undangundang Nomor 35 tahun 2014 tentang perubahan atas Undang-undang Nomor 23 Tahun 2002.
\end{abstract}

Kata Kunci: Perceraian, Mulih daha, Hak Anak

\begin{abstract}
Women who return to their original homes because of a divorce, their status is called mulih daha (girls return). With this, the mulih daha woman continues to carry out her swadharma (obligations) to her parents at her home. If the marriage breaks up due to divorce, it also has legal consequences for the child. Based on the background that has been described, the purpose of this study is to find out how the legal status of the Mulih Daha woman is and what are the legal consequences for the child brought by the Mulih Daha woman to her home. The research method in this writing uses empirical research methods. The results of this study indicate that mulih daha women have no right to claim back the right to inherit in their home of origin. The rights and obligations of parents who have divorced their children must still be carried out as stipulated in Article 26 paragraphs (1) and (2) of Law Number 35 of 2014 concerning amendments to Law Number 23 of 2002.
\end{abstract}

Keyword: Divorce, Mulih Daha, Children's Rights

\section{PENDAhUluan}

Adat istiadat, serta kebiasaan dari sekian banyak perbedaan yang ada pada suku-suku bangsa di Indonesia, yang cukup menjadi perhatian kita untuk dibahas salah satunya adalah tata aturan ditiap suku bangsa itu sendiri yang kerap disebut dengan hukum adat. Definisi hukum adat yakni hukum yang hidup mewujudkan hukum nyata dari masyarakat dan sesuai dengan hakikatnya, hukum adat akan terus menerus tumbuh dan berkembang seperti hidup itu sendiri (Supomo, 1993). Kita ketahui bersama bahwa dalam Hukum Adat Perkawinan itu bukanlah sekedar suami dan istri saja, tetapi merupakan hubungan dari keluarga pihak suami dan juga keluarga pihak istri sehingga dalam pemilihan seorang calon istri dan calon suami harus mendapatkan dukungan atau persetujuan penuh dari kedua belah pihak. Disamping itu juga perkawinan merupakan bagian dari kehidupan manusia, karena dengan dasar perkawinan inilah diharapkan akan mendapatkan anak sebagai penerus keturunan (P.Windia, 2014).

Ikatan perkawinan ini selalu akan diatur oleh hukum, yaitu untuk menentukan hak dan kewajiban dari masing-masing suami dan istri dalam masalah kehidupan keluarga yang harus dilengkapi, serta hak dan kewajiban sebagai suami terhadap istri maupun anak-anaknya. Sebagai suami istri adalah merupakan suatu kewajiban untuk saling mencintai dan menghormati serta saling memberikan bantuan baik lahir maupun batin. Perkawinan itu hendaknya menuju kepada kebahagiaan dan kesejahteraan baik materil maupun spiritual, untuk menuju kekekalan dalam menjalani perkawinan. Seperti dalam Pasal 1 Undang-Undang Nomor 1 Tahun 1974 menyatakan bahwa perkawinan adalah ikatan lahir batin antara 
seorang pria dan seorang wanita sebagai suami istri dengan tujuan membentuk keluarga (rumah tangga) yang bahagia kekal berdasarkan Ketuhanan Yang Maha Esa (Atmadja \& Budiartha, 2019)

Namun tidak semua perkawinan itu dapat berjalan dengan normal sesuai dengan apa yang mereka harapkan. Hal ini disebabkan oleh karena adanya salah satu pihak tidak dapat menjalankan kewajiban sebagai mana mestinya. Disamping putusnya suatu perkawinan disebabkan pula oleh karena adanya salah satu pihak yang meninggal dunia, maka mereka yang masih hidup tersebut dinamakan dengan Balu. Bila putusnya perkawinan karena perceraian maka mereka disebut dengan Sapihan (duda atau janda) ini berarti tidak ada yang kalah dan yang menang. Terjadinya perceraian hendaknya harus dihindari, namun demikian dalam kenyataan yang terjadi di masyarakat Bali masih banyak terjadinya kasus perceraian.

Perkawinan putus dikarenakan terjadinya suatu perceraian menjadikan dasar adanya perempuan yang mulih daha, Mulih berarti kembali dan Daha berarti gadis . Tetapi tidak seluruh perempuan yang mengalami perceraian dapat berstatus sebagai mulih daha, kedudukan pada perempuan yang mulih daha tidak selalu melekat pada seorang janda, sehingga perempuan yang mulih daha memperoleh kedudukan sebagai seorang gadis atau daha. Mulih daha harus dikembalikan ke rumah asalnya dengan adanya persetujuan dari pihak keluarganya maupun saudara- saudara yang lain yang masing- masing mempunyai ikatan atau di Bali bisa disebut dengan tali senang. Terjadinya suatu perceraian juga mempunyai akibat hukum terhadap anak yang dilahirkan dari pasangan suami istri yang melakukan perceraian. Orang tua yang sudah melakukan proses perceraian pun tetap harus bertanggung jawab terhadap anak- anaknya. Kewajiban orang tua terhadap anak-anak mereka juga tetap harus dilakukan meskipun perkawinan dari kedua orang tua putus (Sugiarto, 2014). Kedua orang tua wajib memelihara dan mendidik anak-anaknya sampai anak sudah menyelesaikan pendidikannya di perguruan tinggi dan mampu hidup dengan mandiri.

Perceraian dalam hukum adat Bali terdapat istilah Mulih Daha. Istilah Mulih Daha dapat diartikan di mana setelah perceraian berlangsung maka seorang perempuan akan kembali ke keluarga asalnya dengan harapan orangtua atau saudara laki-laki dapat menerimanya kembali. Jika melihat pada Keputusan Pasamuan Agung MUDP ke-III, Perempuan yang cerai harus diterima dengan satus mulih daha, artinya dia kembali dalam posisi seperti anak yang lajang. Artinya, untuk seterusnya mereka akan melaksanakan kewajiban (swadharma) dan mempunyai hak (swadikara) di keluarga asal lagi (Budawati, 2012).

Keberagaman yang ada di Indonesia tentu juga termasuk dengan masyarakat hukum adatnya beserta dengan adat istiadatnya. Dalam hukum adat mengartikan perceraian sebagai suatu perkawinan yang putus antara suami dan istri. Dalam perceraian terdapat istilah Mulih Daha dapat diartikan di mana setelah perceraian berlangsung maka seorang perempuan akan kembali kekeluarga asalnya dengan harapan orangtua atau saudara lakilaki dapat menerimamya kembali (Dwijanata \& Griadhi, 2020). Pada kenyataan hidup berumah tangga ada kalanya dalam suatu perjalanan hidup yang ditempuh tidaklah seindah apa yang dicita-citakan semula perkawinan yang rukun dan bertahan sampai dengan kakek nenek dan bahkan sampai dengan akhir hayatnya. Bahwa tidak semua perkawinan itu dapat berjalan dengan normal sesuai dengan apa yang mereka harapkan (Yudiantara et al., 2013). Kedudukan dan peranan perempuan mulih daha baik itu dalam keluarga dan juga masyarakat dianalisis menggunakan TeorStruktural Fungsionalis dari Merton, yakniterkait dengan tiga postulat yang dikritiknyaserta tentang yang ia jelakan mengenastruktur, budaya, serta fungsi yang salingberkaitan. Pada intinya, budaya patrilinial di Bali memberikan banyak pengaruhterhadap proses penerimaan perempuanmulih daa tersebut baik dalam lingkupkeluarga maupun masyarakat (Gatriyani et al., 2018).

Dari paparan diatas dirumuskan tujuan dari penelitian ini untuk mengetahui status hukum perempuan Mulih Daha (kembali gadis) dalam sistem kekeluargaan di Desa Adat Mengwitani. Disamping itu, untuk mengetahui akibat hukum terhadap anak yang dibawa perempuan Mulih Daha (kembali gadis) di Desa Adat Mengwitani

\section{METODE PENELITIAN}

Metode penelitian yang digunakan dalam menyusun penelitian ini adalah penelitian hukum empiris. Penelitian hukum empiris ini merupakan salah satu yang dapat ditempuh untuk mendapatkan fakta empiris yang dapat diperoleh pada perilaku manusia, yang didapatkan dengan melalui wawancara maupun perilaku nyata yang dilakukan dengan pengamatan langsung. Dengan menggunakan pendekatan perundang- undangan, pendekatan sosiologis dan pendekatan konseptual (Sulistiowati 
Iriyanto, 2009). Sumber data hukum yang digunakan dalam penelitian ini berupa sumber data primer dan sumber data sekunder, data primer yang digunakan yaitu data yang diperoleh dari sumber pertama (responden/informan) yang diperoleh dari lapangan dimana daftar yang berasal dari hasil observasi atau pengamatan secara langsung ke tempat kejadian dan melalui wawancara. Sedangkan data sekunder yang digunakan yaitu berbagai bahan kepustakan yaitu Awig-Awig Desa Adat Mengwitani, litelaturlitelatur buku, jurnal, maupun hasil penelitian yang berhubungan dengan pembahasan penelitian. Teknik pengumpulan data hukum yang digunakan yaitu teknik pengumpulan data primer yaitu dengan teknik wawancara, dengan mewawancarai informan yang berkaitan dengan permasalahan yang akan dibahas. Dan analisis data yang dipergunakan yaitu analisis kualitatif yang disajikan secara deskriptif sesuai dengan hasil penelitian lapangan dan kepustakaan agar dapat memperoleh kesimpulan yang tepat dan logis

\section{PEMBAHASAN}

\section{Status Hukum Perempuan Mulih Daha (kembali gadis) Dalam Sistem Kekeluargaan di Desa Adat Mengwitani}

Perceraian pada sistem hukum adat di Bali terdapat istilah yaitu mulih daha (kembali gadis), istilah dari perempuan yang mulih daha dapat dikatakan dimana setelah proses bercerai terjadi maka seorang perempuan akan kembali ke keluarga atau rumah asalnya dengan harapan orang tua atau saudara lakilaki dapat menerimanya kembali. Sebagai kata majemuk mulih daha mengandung arti mulih berarti kembali asal sedangkan daha untuk menjadi dara atau gadis, dari kata majemuk yang mempunyai pengertian hukum yaitu mengembalikan kedudukan seorang wanita yang yang sudah pernah melakukan perkawinan (K.I.G. Ketut, 2007).

Perempuan mulih daha di Desa Adat Mengwitani yang kembali ke rumah asalnya sudah melakukan proses perceraian sesuai dengan peraturan Undang-Undang dan peraturan Adat. Tidak semua perempuan mulih daha melakukan proses perceraian secara hukum, tetapi ada yang hanya melalui proses adat saja. Berdasarkan dari hasil wawancara penulis dengan Bapak I Putu Wendra, selaku kelian Desa Adat Mengwitani pada hari jumat tanggal 19 maret 2021 Perempuan mulih daha di Desa Adat Mengwitani yang sudah melakukan proses perceraian melalui Prajuru Adat/Banjar dan dilanjutkan dengan penyelesaian secara kekeluargaan setelah itu dilakukannya upacara mepamit pada leluhur di kediaman suami dan diantar ke rumah asalnya oleh pihak keluarga suaminya dan dikembalikan dengan cara baik dan sopan ke pihak keluarga perempuan. Ketentuan ini telah diatur sebagaimana yang tercantum pada awig-awig di Desa Adat Mengwitani tertulis Pawos (pasal) 73 Indik Sapihan, yang menentukan sebagai berikut Sang maparabian palas makurenan Kamanggehang Yaning silih tunggil tan maren memunyah, memitra, mamotoh, boros meadep-adepan tanpa unduk, tan sida mgawetuang sentana, mati semara, tan lingu ring perumahan, muwang pakadang miwah parahyangan, tan lingu ring tatenganan-tatengan sewosan, tan satinut ring pangelemek wong katah minakadinia Prajuru.

a. Kemanggehang Yaning kurenan luh sane wantah mapadewekan luh sane melaksana wyadin makahanan sakadi ring ajeng, wenang kawalingan sungkaning becik-becik kaumah danene pecak, inggih punika kapalasang mulih bajang.

b. Kemanggehang Yan sane muani padewekan luh sane melaksana wyadin makahanan sakadi ring ajeng, taler wenang kawaliang sangkaniang becik-becik kaumah danene pecak, inggih punika kapalasang mulih taruna.

c. Kemanggehang tiyosang ring dasar-dasar kadi ring ajeng, tan pisan dados ngamaduang wiadin malasang kurenan, sajawaning sampun polih lugraha saking kurenan ipun wiyadin pianak ipune

d. Kemanggehang Sang sane memurug, wenang kapidanda marupa danda seageng-agengnyane 275 keteng jinah bolong.

e. Kemanggehang makasami pariindikan puniki patut kasaksinin olih Prajuru Banjra mwang Prajuru Desa Adat malaparan antuk surat-surat piteket sepatutnyane pinaka pakukuh perjanjianperjanjian wiara puniki.

Karena perempuan mulih daha (kembali gadis) itu merupakan akibat dari perceraian akan tetapi perceraian ini tidak selalu diikuti oleh mulih daha (kembali gadis) tetapi hal ini harus dapat dibuktikan dengan beberapa persyaratan seperti dibawah ini:

a. Adanya pengembalian dengan baik dan penerimaan dengan baik oleh pihak keluarga perempuan.

b. Serah terima dilakukan dirumah si wanita dengan disaksikan oleh prajuru Adat bersangkutan. 
c. Adanya upacara Agama seperti upacara pesaksian sebagai rasa hormat kepada keluarganya.

d. Adanya pemutusan uang kepeng sebagai bukti bahwa perkawinannya telah putus atau cerai. Perempuan yang mulih daha (kembali gadis) mempunyai hak atas nafkah dari sisa harta atas kekayaan orang tuanya dengan tidak mengesampingkan keluarga lelaki lainnya. Namun persyaratan di atas tidak terdapat pada awig-awig banjar dan persyaratan tersebut menjadi awig-awig tidak tertulis atau Perarem karena merupakan aturan pelaksanaan perarem Desa Adat yang dibuat untuk mengatur hal yang belum diatur pada awig-awig Banjar. Ketentuan ini berdasarkan hasil wawancara penulis dengan Bapak I Ketut Gede Jaya , selaku Kelian Banjar Loda Pura, Desa Adat Mengwitani, pada hari minggu, Tanggal 16 Mei 2021. Dengan adanya mulih daha (kembali gadis), seorang perempuan mulih daha mendapatkan kembali swdharmanya (kewajibannya) selaku anggota keluarganya sebagai semula sebelum melakukan perkawinan keluar dari lingkungan keluarga asalnya tersebut. Kewajiban yang mereka lakukan dalam keluarga dan masyarakat di Desa Adat Mengwitani yaitu ikut serta membantu apapun yang berkaitan di dalam keluarga asalnya baik itu dalam hal perekonomian, masalah-masalah keluarga, dan ikut membantu orang tua dalam hidup bermasyarakat (menyama braya), perbedaan mendasar pada perempuan mulih daha adalah mereka yang telah menjadi orang tua. Perempuan mulih daha di Desa Adat Mengwitani tidak dapat berstatus sebagai purusa, kecuali adanya itikad baik dari orang tua sehingga dapat diberikan warisan.

\section{Akibat Hukum Terhadap Anak yang dibawa Perempuan Mulih Daha (Kembali gadis) Di Desa Adat Mengwitani}

Akibat hukum dalam perceraian pada anak tentu saja hanya berlaku kepada suami dan istri yang mempunyai keturunan atau anak dalam perkawinan mereka, seperti disebutkan dalam Pasal 41 UndangUndang Nomor 1 Tahun 1974 tentang Perkawinan. Apabila dikaitkan dengan anak dalam korban perceraian dari kedua orang tua maka pengadilan harus membuatkan keputusan untuk kepentingan terhadap anak, dan tidak dari kepentingan orang tuanya saja. Agar hak-hak pada anak terjadi dan anak dapat tumbuh serta mampu berkembang dengan baik. Perlindungan hukum pada anak sebagai salah satu upaya agar tujuan hukumnya dapat tecapai.

Tujuan dari perlindungan hukum yang dimaksud yaitu agar dapat terpeliharanya keamanan serta ketertiban sehingga dapat dikatakan untuk menjamin adanya kepastian hukum, dengan demikian dapat dihindari tindakan-tindakan yang tidak baik dari pihak tertentu. Dapat dikatakan perlindungan hukum pada anak dapat diartikan sebagai kebebasan dan hak asasi pada anak serta sebagai kepentingan yang berhubungan dengan kesejahteraan anak (Barda Nawawi Arief, 2013).

Pengertian tentang anak yang telah diatur dari beberapa aturan dan perundang-undangan diantaranya yaitu kitab Undang-Undang Hukum Perdata yang dijelaskan tentang pengertian terhadap anak dengan istilah belum dewasa dan mereka yang masih dalam pengasuhan dari orang tua dan wali, yaitu dalam Pasal 330 KUHPerdata mengatakan bahwa orang yang belum dewasa adalah anak yang belum mencapai usia genap 21 (dua puluh satu) tahun dan tidak lebih dahulu setelah menikah. Sama dari penjelasan diatas orang tua wajib memelihara anak mereka sampai anak tersebut tumbuh dewasa dengan baik.

Maka dari itu anak berhak atas pelayanan dari orang tuanya agar berkembangnya kemampuan dari kehidupan sosial anak, serta anak berhak atas pemelihara dan perlindungan yang sama baik pada saat dalam kandungan maupun sudah/setelah dilahirkan. Perlindungan hukum bagi anak yang dibawa oleh perempuan mulih daha (kembali gadis) di Desa Adat Mengwitani juga mendapatkan perlindungan hukum sebagaimana mestinya seperti penjelasan diatas, dimana anak tersebut mendapatkan pengasuhan, pemeliharaan, pendidikan dan perlindungan dari kedua orang tuanya.

Orang tua adalah lingkungan pertama yang melihat tumbuh dan berkembangnya anak. Hak serta kewajiban dari orang tua terhadap anak dari korban perceraian yang mengutamakan kepentingan anak yaitu hak-hak pada anak yang menyangkut biaya hidup dan pendidikan secara keseluruhan, dan tidak terlepas dari kasih sayang kedua orang tuanya (Syaifuddin et al., 2013). Kewajiban orang tua terhadap anak diatur dalam Pasal 26 ayat (1) Undang-Undang Nomor 35 Tahun 2014 tentang perubahan atas Undang-Undang Nomor 23 Tahun 2002 dapat dikatakan yaitu:

a. Orang tua berkewajiban dan bertanggung jawab untuk

b. Mengasuh, memelihara, mendidik, dan melindungi anak

c. Menumbuh kembangkan anak sesuai dengan kemampuan, bakat, dan minatnya

d. Mencegah terjadinya perkawinan pada usia anak dan 
e. Memberikan pendidikan karakter dan penanaman nilai budi pekerti pada anak.

Akibat hukum terhadap kewajiban orang tua dalam mendidik serta memelihara anak adalah tanggung jawab bersama orang tua baik itu suami maupun istri. Walaupun dalam mendidik dan memelihara anak adalah tanggung jawab suami namun dalam hal tersebut jika suami/ayah tidak dapat bertanggung jawab maka diambil alih oleh si ibu dari anak tersebut yang dalam arti perhatian ibu lebih besar terhadap anaknya yang masih kecil dan masih dibawah umur, hendaknya dengan kasih sayang ibu terhadap anaknya atau dilakukan secara bersamaan oleh ibu dan ayah sesuai kemampuan dari masing pihak (Rahmadi I.T, 2012). Hal ini dimaksud agar anak tidak menjadi korban dalam perceraian dari kedua orang tuanya.

\section{SIMPULAN DAN SARAN \\ 1. Simpulan}

Berdasarkan uraian pembahasan terhadap permasalahan di atas dapat ditarik kesimpulan sebagai berikut yakni, status hukum perempuan mulih daha (kembali gadis) dalam sistem kekeluargaan di Desa Adat Mengwitani tidak dapat berstatus sebagai purusa, kecuali ada itikad baik dari orang tua sehingga dapat diberikan warisan. Serta untuk seterusnya perempuan mulih daha (kembali gadis) yang kembali ke rumah asalnya akan melaksanakan kewajibannya (swadharmanya). Sehingga dapat dipastikan sebagai dimana setelah perceraiannya terjadi maka perempuan mulih daha (kembali gadis) kembali ke rumah asalnya atau ke keluarga asalnya dengan harapan keluarga dan saudara laki-lakinya menerimanya kembali dengan baik. Akibat hukum terhadap anak yang dibawa perempuan mulih daha (kembali gadis) sama statusnya dengan anak-anak yang lainnya yang berdasarkan pada UndangUndang Nomor 35 tahun 2014 atas perubahan Undang-Undang Nomor 23 Tahun 2002 tentang Perlindungan Hukum Terhadap Anak yang dapat diartikan sebagai upaya perlindungan hukum terhadap berbagai kebebasan dan hak asasi anak serta sebagai kepentingan yang berhubungan dengan kesejahteraan anak.

\section{Saran}

Berdasarkan uraian pembahasan terhadap permasalahan diatas maka dapat disampaikan saran sebagai berikut, kepada para perempuan yang akan mulih daha (kembali gadis) sebelum melakukan perceraian diperlukan ketentuan hukum dalam awig-awig di Desa Adat Mengwitani. Agar perempuan mulih daha (kembali gadis) mengetahui bagaimana status hukum serta kewajibannya di rumah asalnya. Kepada orang tua dari anak yang menjadi korban perceraian tetap berkewajiban untuk memelihara anak tersebut sampai anak tumbuh dewasa dan bisa mandiri. Terutama dalam pembiayaan pendidikan sampai jenjang perguruan tinggi, agar di kehidupan selanjutnya anak tersebut bisa hidup dengan mandiri.

\section{DAFTAR PUSTAKA}

Atmadja, I. D. G., \& Budiartha, I. N. P. (2019). Filsafat Hukum (Cet.1). Setara Press. Malang. Budawati, N. N. (2012). Buku Saku Seri Adat Bali Payung Adat Untuk Keluarga Bali. Denpasar. Dwijanata, A. A. B. C., \& Griadhi, N. M. A. Y. (2020). Kedudukan Hukum Anak Perempuan Yang Ninggal Kedaton Pasca Perceraian Dalam Perspektif Hukum Adat Bali. Kertha Desa, Vol.8(3).

Gatriyani, N. K. A., Kebayantini, N. L. N., \& Nugroho, W. B. (2018). Kedudukan dan Peranan Perempuan Mulih Daa dalam Keluarga dan Masyarakat di Desa Pakraman Padangsambian Kecamatan Denpasar Barat. Jurnal Ilmiah Sosiologi, Vol. 1.

P.Windia, W. (2021). Hukum Adat Bali Aneka Kasus dan Penyelesaian. Udayana University Pres Denpasar.

Rahmadi. (2012). Kepastian Hukum Terhadap Perlindungan Hak Anak Korban Perceraian. Kajian Gender, Vol. 4(1).

Soepomo. (1993). Hukum Acara Perdata Pengadilan Negeri. PT Pradnya Paramita. Jakarta.

Syaifuddin, M., Turatmiyah, S., \& Yahanan, A. (2013). Hukum Perceraian (Cet.1). Sinar Grafika. Jakarta.

Sugiarto, U. S. (2014). Pengantar Hukum Indonesia. Sinar Grafika. Jakarta.

Yudiantara, I. G. E. J., Sudiatmaka, K., \& Windari, R. A. (2013). Kedudukan wanita Bali dalam hukum adat Bali (Sudi Kasus Hak dan Kewajiban Wanita Balu dalam Hukum Adat Di Desa Belega, Kecamatan Blahbatuh, Kabupaten Gianyar). Undiksha. 